\title{
Non-adherence to anti- diabetic therapy and its consequences among type-2 diabetic patients in a tertiary care hospital
}

\author{
Veeresh J.*, Vasanth R. Chavan, Mohammad Arshad, \\ Raghunandan M., Mohd. Fayazuddin
}

Department of Pharmacology, Raichur Institute of Medical Sciences, Raichur, Karnataka, India

Received: 09 April 2017

Accepted: 28 April 2017

*Correspondence to:

Dr. Veeresh J.,

Email: ucanmailveeru@

gmail.com

Copyright: (C) the author(s), publisher and licensee Medip Academy. This is an openaccess article distributed under the terms of the Creative Commons Attribution NonCommercial License, which permits unrestricted noncommercial use, distribution, and reproduction in any medium, provided the original work is properly cited.

\begin{abstract}
Background: Despite the extensive therapy options available for various stages of type 2 diabetes, studies have indicated that less than $50 \%$ of patients achieve the glycemic goals. Failure to attain the desired therapeutic goal might be related to inadequate adherence. Objectives of present study were to determine the extent of non-adherence to antidiabetic medications and identify reasons for the same.

Methods: A cross-sectional, observational, questionnaire-based study was conducted to assess the level of non-adherence to antidiabetic therapy among type 2 diabetics attending medicine outpatient department or admitted to the wards of a tertiary care hospital from Jan 2015 to Jan 2016. A pretested and validated questionnaire was used to assess the level of adherence. Reasons for missing medications were also elicited. Data thus collected was analysed using a suitable statistical software.

Results: Out of the 210 study participants, 55.2\% were females. Most participants were in the age group of 51-60. The mean duration of diabetes was $8.17 \pm 5.39$. The most common diabetes-related complication was Diabetic Keto Acidosis (DKA), followed by diabetic foot ulcer. The average number of drugs per prescription was $1.98 \pm 1.05$. Poor glycemic control was observed in $58 \%$ and non-adherence to treatment in $45.2 \%$ of study participants.

Conclusions: Good adherence to antidiabetic therapy is fundamental for good glycemic control which in turn prevents the occurrence of short and long-term complications of diabetes. Poor doctor-patient intercommunication and inadequacy on part of physicians to adjust medications negatively affect adherence. Active participation of the patient is also equally important.
\end{abstract}

Keywords: Glycemic control, Non-adherence, Type 2 diabetes

\section{INTRODUCTION}

Diabetes mellitus (DM) is a chronic metabolic disorder characterized by hyperglycemia due to disturbances of carbohydrate, fat and protein metabolism resulting from defects in insulin secretion, insulin action, or both. ${ }^{1}$ Current global prevalence of 415 million is expected to rise to 642 million $\left(54.7 \%\right.$ increase) by $2040 .^{2}$ The estimated prevalence of 65.1 million in India is expected to rise to 101.2 million (65\% increase) by 2030 resulting in every fifth person with diabetes in the world to be an
Indian. ${ }^{3}$ This is the reason why India has been deemed as the global capital of Diabetes Mellitus. ${ }^{4}$

Treatment of diabetes includes dietary changes, lifestyle modifications and pharmacotherapy aimed at preventing and controlling hyperglycemia. The direct and indirect effects of hyperglycemia on the human vascular tree are the major source of morbidity and mortality in both type 1 and type 2 diabetes. The injurious effects of hyperglycemia are separated into macrovascular complications (coronary artery disease, peripheral arterial 
disease, and stroke) and microvascular complications (diabetic nephropathy, neuropathy, and retinopathy). ${ }^{5}$

Most patients with type 2 diabetes fail to control blood glucose with diet and exercise and require pharmacotherapy. In general, initially, monotherapy with an Oral Hypoglycemic Agents (OHA) is started. However, owing to the progressive nature of the disease, most of the patients will eventually require combination therapy and ultimately injectable treatments as monotherapy or part of polytherapy. ${ }^{6}$

Adherence, as used in chronic disorders, was defined by the WHO as the extent to which a person's behavior with respect to taking medication, following a diet, and/or executing lifestyle changes, corresponds with agreed recommendations from a healthcare provider. Reduced adherence not only results in poor health outcomes but it also has a significant impact on healthcare costs. ${ }^{7}$

There is a need to assess non-adherence on a regular basis as it keeps on changing due to changes in lifestyle, new medicines in the market with varied dosing, adverse effect profile or interactions with other drugs. Hence, this cross-sectional study was conducted with an aim to identify the factors associated with non-adherence to antidiabetic therapy and develop strategies for ensuring timely and appropriate intervention.

\section{METHODS}

The present study was a cross-sectional, observational, questionnaire-based study. After obtaining Institutional Ethical Committee approval, the study was conducted among 210 type 2 diabetic patients attending medicine outpatient department or admitted in wards of a tertiary care centre during the period from January 2015 to January 2016.

A case record form was carefully designed to capture: demographic details, disease, and treatment-related information and relevant investigations of the study participants.

To assess patient adherence to treatment, Morisky Medication Adherence Scale-8 (MMAS-8) (alphareliability $=0.83$ ), a pretested and validated questionnaire was used (Table 1). ${ }^{8-10}$ Various reasons for missing medications were also enquired (Table 2). Data thus collected was analysed using SPSS software version 16 .

\section{Inclusion criteria}

Type 2 diabetic patients aged 18-80 yrs, who have received treatment for at least 6 months

\section{Exclusion criteria}

Patients with type 1 diabetes or gestational diabetes or those with psychiatric illness.
Table 1: MMAS-8 for measurement of adherence.

\begin{tabular}{|c|c|}
\hline Question & Response \\
\hline $\begin{array}{l}\text { Do you sometimes forget to take your } \\
\text { pills? }\end{array}$ & Yes/No \\
\hline $\begin{array}{l}\text { People sometimes miss taking their } \\
\text { medications for reasons other than } \\
\text { forgetting. Thinking over the past two } \\
\text { weeks, were there any days when you } \\
\text { did not take your medicine? }\end{array}$ & Yes/No \\
\hline $\begin{array}{l}\text { Have you ever cut back or stopped } \\
\text { taking your medicine without telling } \\
\text { your doctor because you felt worse } \\
\text { when you took it? }\end{array}$ & Yes/No \\
\hline $\begin{array}{l}\text { When you travel, or leave home, do you } \\
\text { sometimes forget to bring along your } \\
\text { medicine? }\end{array}$ & Yes/No \\
\hline $\begin{array}{l}\text { Did you take all your medicine } \\
\text { yesterday? }\end{array}$ & Yes/No \\
\hline $\begin{array}{l}\text { When you feel like your symptoms are } \\
\text { under control, do you sometimes stop } \\
\text { taking your medicine? }\end{array}$ & Yes/No \\
\hline $\begin{array}{l}\text { Taking medicine every day is a real } \\
\text { inconvenience for some people. Do you } \\
\text { ever feel hassled about }\end{array}$ & Yes/No \\
\hline \multirow{5}{*}{$\begin{array}{l}\text { How often do you have difficulty } \\
\text { remembering to take all your medicine? }\end{array}$} & Never/rarely \\
\hline & $\begin{array}{l}\text { Once in a } \\
\text { while }\end{array}$ \\
\hline & Sometimes \\
\hline & Usually \\
\hline & All the time \\
\hline \multicolumn{2}{|c|}{$\begin{array}{l}\text { MMAS- } 8 \text { consists of eight items with a scoring scheme of "Yes" } \\
=0 \text { and "No" }=1 \text { for the first seven items and a } 5 \text {-point Likert } \\
\text { response for the last item. A total score for } 8 \text { questions of the } \\
\text { MMAS- } 8 \text { questionnaire was calculated for each of the study } \\
\text { participants. The range of score was from } 0-8 \text {. Optimal } \\
\text { adherence was defined as having a MMAS- } 8 \text { score over } 6 \text { out of } \\
\text { a total of } 8 \text {. }\end{array}$} \\
\hline
\end{tabular}

\section{RESULTS}

The data obtained from these 210 study participants is represented here after applying appropriate statistical tests wherever necessary. $116(55.2 \%)$ of the respondents were females and the remaining were males. $70(33 \%)$ of the participants were in the age group of 51-60 and the mean age of study participants was $54.92 \pm 10.25$. Mean duration of DM was 8.17 \pm 5.39 yrs. The most common diabetes-related complication was Diabetic Keto Acidosis (DKA), followed by diabetic foot ulcer (Table 3). The average number of drugs per prescription was $1.98 \pm 1.05$ and Metformin was the most commonly prescribed oral hypoglycemic. Non-adherence to treatment was observed in $45.2 \%$ and poor glycemic control in $58 \%$ of study participants. Statistically significant association $(\mathrm{p}<0.01)$ was found between non-adherence to treatment and poor glycemic control.

Those who had diabetes-related complications and those who took oral hypoglycemics were most adherent to 
treatment compared to those who were put on insulin alone or insulin with oral hypoglycemic. The most common reason for non-adherence was not being aware of the consequences of missing the doses (62) followed by forgetting to take medications along while traveling (47) and forgetfulness (47).

Table 2: Reasons for missing medications

\begin{tabular}{|c|c|}
\hline Reason & Response \\
\hline Forgetfulness & Yes/ No \\
\hline Being busy & Yes/ No \\
\hline Fear of taking too many drugs & Yes/ No \\
\hline Economic problems & Yes/ No \\
\hline Because of side effects & Yes/ No \\
\hline $\begin{array}{l}\text { Lack of information about disease and } \\
\text { treatment }\end{array}$ & Yes/ No \\
\hline $\begin{array}{l}\text { Not aware of consequences of missing } \\
\text { doses }\end{array}$ & Yes/ No \\
\hline Shifted to Ayurveda/ homeopathy/ others & Yes/ No \\
\hline Difficulty in visiting physician & Yes/ No \\
\hline $\begin{array}{l}\text { Forget to take medications along while } \\
\text { travelling }\end{array}$ & Yes/ No \\
\hline Any other reason & \\
\hline
\end{tabular}

Table 3: Distribution of study subjects based on diabetes related complications.

\begin{tabular}{|lll|}
\hline Complications & Frequency & Percent \\
\hline DKA & 11 & 5.2 \\
\hline Hypoglycemia & 7 & 3.3 \\
\hline Cellulitis & 4 & 1.9 \\
\hline Diabetic foot ulcer & 8 & 3.8 \\
\hline Myocardial infarction & 5 & 2.4 \\
\hline
\end{tabular}

\section{DISCUSSION}

Despite the extensive therapy options available for various stages of type 2 diabetes, studies have indicated that less than $50 \%$ of patients achieve the glycemic goals recommended by the American Diabetes Association (ADA) and approximately two-thirds die prematurely of cardiovascular disease. ${ }^{11}$

Failure to attain the desired therapeutic goal might be related to inadequate adherence. Instead of changing the prescription, increasing the drug dosage, or adding a new drug, adherence assessment to the treatment should be considered first in most patients. ${ }^{12}$

In our study, poor glycemic control was seen in $58 \%$ of the study participants. This is consistent with the findings of many studies like that done by Wabe et al and Nagpal et al. ${ }^{13,14}$ Our study also established that around $45 \%$ of the participants were non-adherent to treatment like studies done by Medi et al $(52.15 \%)$ and Arulmozhi et al $(50.7 \%){ }^{15,16}$ These variations in estimates of adherence between studies may be due to several factors like different methodologies for measurement of adherence, different patient populations (socioeconomic effects) and differences in the cut-off point used for defining adherence.

The most common reasons for missing the medications were not being aware of consequences of missing the doses, forgetting to take along the medications while traveling followed by lack of information on disease and treatment, due to adverse effects of drugs and forgetfulness. A similar finding was found in the study done by Divya et al and Sharma et al. ${ }^{10,17}$ The physicianpatient relationship plays a very important role in informing the patient about the disease and medications which affect adherence. Patients who did not have adequate information about their disease or drug regimens well were probably at a greater risk of non-adherence because they had not understood how and why to take their medications, causing them to miss on many occasions.

It is evident from various studies that medication adherence can be improved by dosage simplification, educating the patients on aspects of drugs, disease state and lifestyle modifications, using reminder systems like pill boxes and packaged calendars. Medication reminder applications over smartphone may help improve medication adherence, but their reliability is yet to be tested.

The study confirms that good adherence to antidiabetic therapy is fundamental for good glycemic control which in turn prevents the occurrence of short and long-term complications of diabetes. Poor doctor-patient intercommunication and inadequacy on part of physicians to adjust medications negatively affect adherence. Also, patients should be informed that diabetes is a chronic disease and requires persistent treatment which won't succeed without their active participation.

\section{ACKNOWLEDGMENTS}

Authors wholeheartedly thank both the teaching and nonteaching staff of Department of Pharmacology and Department of Medicine for their overwhelming support.

Funding: No funding sources

Conflict of interest: None declared

Ethical approval: The study was approved by the Institutional Ethics Committee

\section{REFERENCES}

1. American Diabetes Association. Diagnosis and classification of diabetes mellitus. Diab Care. 2009;32(Suppl 1):S62-S67.

2. Ogurtsova K, Linnenkamp U, Guariguata L, Whiting D, Shaw J, da Rocha Fernandes JD, et al. IDF Diabetes Atlas: Global estimates for the prevalence of diabetes for 2015 and 2040. Diabetes Res Clin Pract. 2017 Mar 31;128:40-50. 
3. Wild S, Roglic G, Green A, Sicree R, King H. Global Prevalence of Diabetes Estimates for the year 2000 and projections for 2030. Diab Care. 2004;27(5):1047-53.

4. Gupta M, Singh R, Lehl SS. Diabetes in India: a long way to go. Int J Sci Rep. 2015 May;1(1):1-2.

5. Fowler MJ. Microvascular and macrovascular complications of diabetes. Clin Diabetes. 2008 Apr;26(2):77-82.

6. García-Pérez L-E, Álvarez M, Dilla T, Gil-Guillén V, Orozco-Beltrán D. Adherence to therapies in patients with type 2 diabetes. Diabetes Ther. 2013Aug;4(2):175-94.

7. Sabaté E. World Health Organization, editors. Adherence to long-term therapies: evidence for action. Geneva: World Health Organization; 2003;198:3,7,20,42.

8. Morisky DE, Ang A, Krousel-Wood M, Ward H. Predictive validity of a medication adherence measure for hypertension control. J Clini Hypert. 2008;10(5):348-54.

9. Krousel-Wood MA, Islam T, Webber LS, Re RS, Morisky DE, Muntner P. New medication adherence scale versus pharmacy fill rates in seniors with hypertension. Am J Manag Care. 2009;15(1):59-66.

10. Morisky DE, DiMatteo MR. Improving the measurement of self-reported medication nonadherence: Final response. J Clin Epidemiol. 2011;64:258-63.

11. Bailey CJ, Kodack M. Patient adherence to medication requirements for therapy of type 2 diabetes. Int J Clin Pract. 2011;65:314-22.
12. Sharma T, Kalra J, Dhasmana DC et al. Poor adherence to treatment: A major challenge in diabetes. JIACM. 2014;15(1): 26-9.

13. Wabe NT, Angamo MT, Hussein S. Medication adherence in diabetes mellitus and self-management practices among type-2 diabetics in Ethiopia. N Am J Med Sci. 2011;3(9):418-23

14. Nagpal J, Bhartia A. Quality of Diabetes Care in the Middle- and High-Income Group Populace: The Delhi Diabetes Community (DEDICOM) survey. Diab Care. 2006;29(11):2341-8.

15. Medi RK, Mateti UV, Kanduri KR, Konda SS. Medication adherence and determinants of nonadherence among south Indian diabetes patients. J Soc Health Diab. 2015;3(1):48.

16. Arulmozhi S, Mahalakshmy T. Self Care and medication adherence among type 2 diabetics in puducherry, southern india: a hospital based study. JCDR. 2014 Apr;8(4):UC01.

17. Divya S, Nadig P. Factors contributing to nonadherence to medication among type 2 diabetes mellitus in patients attending tertiary care hospital in south India. Asian J Pharmaceu Clini Res. 2015;8(2):274-76.

Cite this article as: Veeresh J, Chavan VR, Arshad M, Raghunandan M, Fayazuddin M. Non-adherence to anti- diabetic therapy and its consequences among type-2 diabetic patients in a tertiary care hospital. Int J Basic Clin Pharmacol 2017;6:1348-51. 